\title{
Pseudomonas syringae subsp. savastanoi (ex Smith) subsp. nov., nom. rev., the Bacterium Causing Excrescences on Oleaceae and Nerium oleander L.
}

\begin{abstract}
J. D. JANSE
Department of Bacteriology, Plant Protection Service, 6700 HC, Wageningen, The Netherlands

From a study of the so-called bacterial canker of ash, caused by a variant of "Pseudomonas savastanoi" (Smith) Stevens, it became evident that this variant and the variants of " $P$. savastanoi" which cause olive knot and oleander knot can be distinguished from one another on the basis of their pathogenicity and host range. All isolates of 'P. savastanoi" were recently classified by Dye et al. (Plant Pathol. 59:153-168, 1980) as members of a single pathovar of $P$. syringae van Hall. It appears, however, that these isolates differ sufficiently from the other members of $P$. syringae to justify subspecies rank for them. The following classification and nomenclature are therefore proposed: Pseudomonas syringae subsp. savastanoi (ex Smith) subsp. nov., nom. rev., to include the olive pathogen (pathovar oleae), the ash pathogen (pathovar fraxini), and the oleander pathogen (pathovar nerii). The type strain of $P$. syringae subsp. savastanoi is ATCC 13522 (= NCPPB 639).
\end{abstract}

"Pseudomonas savastanoi" (Smith 1908) Stevens 1913 was previously used as the name of the bacterium which causes pernicious excrescences on several species of the Oleaceae. (Names in quotation marks are not on the Approved Lists of Bacterial Names [12], have not been validly published since 1 January 1980 , and therefore do not have standing in bacterial nomenclature.) This bacterium was first adequately described from Olea europea L. by Smith (15), who named it "Bacterium savastanoi." A variant from the common ash (Fraxinus excelsior L.) was then described by Brown in 1932 (2) under the name " $B$. savastanoi var. fraxini"; it was later named "P. savastanoi subsp. fraxini" by Dowson in 1943 (5). The variant from Nerium oleander L. (Apocynaceae), which was first described by Ferraris (7) in 1926 as " $P$. tonelliana," was described more adequately by Smith (14), who renamed it " $P$. savastanoi subsp. nerii' 'in 1928.

My recent studies of the so-called bacterial canker of common ash $(7 a, 7 b)$ have yielded biochemical, serological, and pathological data that cast additional light on the nature of the isolates obtained from ash, olive, oleander, privet, and jasmin.

In their proposed nomenclature of the plantpathogenic fluorescent pseudomonads, Young et al. (23) did not distinguish among the different variants, and they classified all isolates of " $P$. savastanoi" as members of $P$. syringae pathovar savastanoi. Their interpretation of the term pathovar, however, is in this case not in agreement with the definition of the term as recom- mended in the International Code of Nomenclature of Bacteria (8).

According to the available data, the present classification and nomenclature of the organisms under discussion are inadequate. The purpose of this paper is to rectify this situation.

\section{MATERIALS AND METHODS}

Bacterial strains. The strains studied are listed in Table 1.

Methods. Descriptions of the methods employed are reported elsewhere (7b).

\section{RESULTS}

Over 40 biochemical and physiological features were determined for the strains. All " $P$. savastanoi" strains had nearly the same characteristics. Significant variances were found only in the production of levan and in the hydrolysis of pectate (not correlated to host plant or pathogenicity) and in the production of indolyl-acetic acid and cytokinin-like compounds. The latter two substances are not produced (or are produced only in very small amounts) by isolates from ash, whereas they are produced by isolates from other host plants. The tests which appear to be useful in differentiating between " $P$. savastanoi" and $P$. syringae are listed in Table 2. For differential characters, also see Sands et al. (11).

All of the "P. savastanoi" strains produced similar titers with an antiserum prepared against strain NCPPB 639 (from Olea europea). The antiserum was absorbed with a cross-reacting $P$. syringae strain (NCPPB 191). After cross-ab- 
TABLE 1. Strains used in this study

\begin{tabular}{|c|c|c|}
\hline \multirow{2}{*}{ Strain $^{a}$} & \multicolumn{2}{|l|}{ Origin } \\
\hline & Host & Country \\
\hline \multicolumn{3}{|l|}{ "P. savastanoi" } \\
\hline PD 109 & F. excelsior L. & Netherlands \\
\hline PD 116 & $F$. excelsior $\mathrm{L}$. & Netherlands \\
\hline PD 119 & $F$. excelsior $\mathbf{L}$. & Netherlands \\
\hline PD 120 & $F$. excelsior $\mathrm{L}$. & Netherlands \\
\hline PD 159 & F. excelsior L. & Netherlands \\
\hline PD 160 & F. excelsior $\mathbf{L}$. & Netherlands \\
\hline PD 161 & $F$. excelsior $\mathbf{L}$. & Netherlands \\
\hline PD 179 & F. excelsior $\mathbf{L}$. & Netherlands \\
\hline PD 206 & F. excelsior $\mathbf{L}$. & Netherlands \\
\hline NCPPB 1464 & $F$. excelsior $\mathrm{L}$. & U.K. \\
\hline NCPPB 1006 & F. excelsior L. & U.K. \\
\hline CNBP 1838 & F. excelsior $\mathrm{L}$. & France \\
\hline NCPPB 639 & O. europea L. & Yugoslavia \\
\hline NCPPB 2327 & O. europea L. & Italy \\
\hline NCPPB 640 & N. oleander L. & Yugoslavia \\
\hline PD 181 & N. oleander L. & Spain \\
\hline NCPPB 2328 & Ligustrum japonicum Thbg. & Italy \\
\hline CNBP 1751 & Jasminum sp. & Greece \\
\hline \multicolumn{3}{|l|}{$P$. syringae } \\
\hline NCPPB 281 & Syringa vulgaris L. & U.K. \\
\hline NCPPB 191 & Persea americana Mill. & Israel \\
\hline NCPPB 981 & Populus canadensis Mnch. 'Eugenei' & U.K. \\
\hline \multicolumn{3}{|l|}{ "P. mors-prunorum" } \\
\hline NCPPB 560 & Host unknown & U.K. \\
\hline "P. maculicola" & & \\
\hline IPO 154 & Brassica oleracea $\mathrm{L}$. & Netherlands \\
\hline \multicolumn{3}{|c|}{ Saprophytic fluorescent pseudomonads } \\
\hline PD 117 & $F$. excelsior $\mathbf{L}$. & Netherlands \\
\hline NCPPB $1465^{b}$ & F. excelsior $\mathbf{L}$. & U.K. \\
\hline
\end{tabular}

${ }^{a}$ The strains are maintained under these names in the collections referred to as follows: PD, Culture Collection of the Plant Protection Service, Wageningen, The Netherlands; NCPPB, National Collection of PlantPathogenic Bacteria, Harpenden, U.K.; CNBP, Collection Nationale de Bacteries Phytopathogènes, Angers, France; IPO, Culture Collection of the Research Institute for Plant Protection, Wageningen, The Netherlands.

" NCPPB 1465 was described as a deviating pathogenic strain of " $P$. savastanoi subsp. fraxini" by Sutic and Dowson (19). In my hands it deviated morphologically, biochemically, and serologically from $P$. syringae subsp. savastanoi and was found to be nonpathogenic on four different hosts. It should therefore be regarded as a saprophytic pseudomonad.

sorption, only the "P. maculicola" strain showed close antigenic relationship to "P. savastanoi" strains.

No significant morphological differences were found between the strains of "P. savastanoi," and only small differences were observed between these strains and the other phytopathogenic pseudomonads tested.

The results of the pathogenicity tests are presented in Table 3. The host plants used were Fraxinus excelsior L., Olea europea L., Nerium oleander L., and Forsythia intermedia Zab.

\section{DISCUSSION}

From my previous studies (7b) and those of others $(2,11,18,19,21,22)$, it has become apparent that " $P$. savastanoi" isolates from different hosts are almost indistinguishable morphologically, biochemically, and serologically.
Only the production of indolyl-acetic acid and cytokinin-like compounds differentiated between the isolates from ash and those from other host plants. These substances are most likely related to pathogenicity, as will be discussed below.

However, the isolates from these different host plants show different pathogenicities and host ranges $(4,7 \mathrm{~b}, 14,18,20)$. The isolates from ash can be clearly distinguished from those of other hosts by a deviating pathogenicity (18; Janse, in press). They evoke wartlike necrotic bark swellings with abundant periderm instead of large, parenchymatous galls. This can possibly be explained by the restricted production of growth substances by isolates from ash. The other isolates of " $P$. savastanoi" 'were found to produce these substances in rather large amounts in vitro, and elevated levels were also 
TABLE 2. Biochemical tests useful in differentiating $P$. syringae subsp. savastanoi from $P$. syringae subsp. syringae ${ }^{a}$

\begin{tabular}{lcc}
\hline \multicolumn{1}{c}{ Tests } & $\begin{array}{c}\text { P. syringae subsp. } \\
\text { savastanoi }\end{array}$ & $\begin{array}{c}\text { P. syringae subsp. } \\
\text { syringae }\end{array}$ \\
\hline Hydrolysis of: & & + \\
Gelatin & - & + \\
Esculin & - & + \\
Arbutin & - or weak & + \\
Casein & - or weak & + \\
Acid from: & & + \\
D-(+)-Raffinose & - & - \\
Erythritol & - & - \\
Alkali from: & & \\
L-(+)-Tartrate & + & \\
\hline
\end{tabular}

${ }^{a}$ Also see Sands et al. (11).

found in their galls $(1,17,22)$. The host range of the isolates from ash is limited to the Oleaceae.

The isolates from olive differ from the isolates from ash by producing large galls instead of necrotic bark swellings; they differ from isolates from oleander in host range (Table 3). Isolates from olive usually do not infect $N$. oleander, and it was for this reason that the oleander organism was originally described as a separate species, " $P$. tonelliana" (7). Although on two occasions $(10,22)$ strains from olive have been reported to infect $N$. oleander, this is generally not the case.

The isolates from oleander form galls and can therefore be distinguished from isolates from ash; they differ from isolates from olive in host range (Table 3).

On the basis of these facts, it is concluded that the bacterial isolates causing excrescences on ash, olive, and oleander must be ranked separately at the level of pathovar as defined in the Bacteriological Code (8) and not as interpreted by Dye et al. (6). Determination of the status of the jasmin and privet isolates requires a more comprehensive host-range study.

Isolates of " $P$. savastanoi" were recently named $P$. syringae pathovar savastanoi $(6,23)$ as a result of investigations (e.g., 3, 9, 11) which have shown that " $P$. savastanoi" is closely related to $P$. syringae van Hall. However, isolates belonging to " $P$. savastanoi" can be readily distinguished biochemically, serologically, and pathologically from $P$. syringae (Table 2) and its subgroups (11); they should therefore be considered at the subspecies level. As the epithet "savastanoi" has had no standing in bacterial nomenclature since 1 January 1980 (12), it is here revived for bacterial pathogens causing excrescences on Oleaceae and $N$. oleander L.

Description of Pseudomonas syringae subsp. savastanoi (ex Smith 1908) subsp. nov., nom. rev. (sa'vas'ta'no.i. M.L. gen. noun savastanoi of
Savastano, named for L. Savastano, the first to study olive knot).

Gram-negative, nonsporeforming rods with rounded ends, 0.3 to 0.7 by 1.0 to $1.8 \mu \mathrm{m}$, occurring singly or in pairs; motile by means of one to five polar flagella. Rather slow-growing, gray-white, smooth, glistening, raised and circular or slightly irregular to undulate colonies are produced on nutrient agar; levan negative or levan positive on nutrient-sucrose $(5 \%)$ agar; produces a weak, blue-green fluorescent, diffusible pigment on King's B medium; some strains produce a brown diffusible pigment. Metabolism is respiratory. Oxidase negative, catalase positive. Acid is produced from $D-(+)$-galactose, glucose, D- $(+)$-ribose, sucrose (slow), D- $(+)$ xylose, and mannitol; no acid is produced from maltose, D-(+)-raffinose, erythritol, or salicin; alkali is produced from L-(+)-tartrate; esculin, arginine, gelatin, and starch are not hydrolyzed; generally, arbutin and casein are not hydrolyzed. Nitrates are not reduced. $\mathrm{H}_{2} \mathrm{~S}$ is not produced from cysteine. No growth occurs in nutrient broth at $37^{\circ} \mathrm{C}$ or with $5 \% \mathrm{NaCl}$. Hypersensitivity is produced in tobacco leaves. The deoxyribonucleic acid contains $60 \mathrm{~mol} \%$ guanine plus cytosine (3). Causes galls and wartlike excrescences on various species of Oleaceae and $N$. oleander $\mathrm{L}$. Gall-forming isolates produce indolyl-acetic acid and cytokinin-like substances in vitro.

The type strain of this subspecies is ATCC 13522 (= NCPPB 639). This strain was isolated by D. Sutic from Olea europea in Yugoslavia. Its description is identical to that of the subspecies, but with the following modifications: levan negative on nutrient-sucrose (5\%) agar; casein hydrolysis is weak; produces galls on $O$. europea L. and $F$. excelsior L.

The following pathovars of $P$. syringae subsp. savastanoi are recognized: pathovar oleae, causing parenchymatic galls on various species of the Oleaceae $(15,16)$; pathovar nerii, causing parenchymatic galls or wartlike excrescences on $N$. oleander L. and various species of the Olea-

TABLE 3. Results of pathogenicity tests with isolates of $P$. syringae subsp. savastanoi on different host plants

\begin{tabular}{lcccc}
\hline Isolate(s) & \multicolumn{4}{c}{ Pathogenicity $^{a}$ on: } \\
\cline { 2 - 5 } \multicolumn{1}{c}{ from: } & Ash & Olive & Oleander & Forsythia \\
\hline Ash & + & + & - & - \\
Olive & $\oplus$ & $\oplus$ & - & - \\
Oleander & $\oplus$ & $\oplus$ & $\oplus$ & - \\
Jasmin & - & $\oplus$ & - & $\oplus$ \\
Privet & $\oplus$ & $\oplus$ & - & - \\
\hline
\end{tabular}

${ }^{a}$ Symbols: + , Necrotic swellings; $\oplus$, parenchymatous galls; -, no pathogenic reaction. 
ceae (14); and pathovar fraxini, causing wartlike excrescences on $F$. excelsior $\mathrm{L}$. and $O$. europea L. $(2,5,13)$.

\section{ACKNOWLEDGMENT}

I am indebted to $H$. J. Miller for his encouragement and help during this investigation.

\section{REPRINT REQUESTS}

Address reprint requests to: J. D. Janse, Department of Bacteriology, Plant Protection Service, Geertjesweg 15, Postbus $9102,6700 \mathrm{HC}$, Wageningen, The Netherlands.

\section{LITERATURE CITED}

1. Beltrá, R. 1961. Effecto morfogenetico observado en los extractos hormonales de los tumores del olivo. Microbiol. Esp. 14:177-187.

2. Brown, N. A. 1932. Canker of ash trees produced by a variety of the olive tubercle organism, Bacterium savastanoi. J. Agric. Res. 44:701-722.

3. De Ley, J. 1968. DNA base composition and hybridization in the taxonomy of phytopathogenic bacteria. Annu. Rev. Phytopathol. 6:63-90.

4. D'Oleivera, M. 1939. Inoculações experimentais com o Bacterium savastanoi E.F. Smith e o Bacterium savastanoi var. fraxini N.A. Brown. Agron. Lusit. 1:88-102.

5. Dowson, W. J. 1943. On the generic names Pseudomonas, Xanthomonas and Bacterium for certain bacterial plant pathogens. Trans. Br. Mycol. Soc. 26:4-14.

6. Dye, B. W., J. F. Bradbury, M. Goto, A. C. Hayward, R. A. Lelliot, and M. N. Schroth. 1980 . International standards for naming pathovars of phytopathogenic bacteria and a list of pathovar names and pathotype strains. Rev. Plant Pathol. 59:153-168.

7. Ferraris, T. 1926. Trattato di patologia e terapia vegetale, vol. 1, 3rd ed. Hopli, Milan.

7a.Janse, J. D. 1981. The bacterial disease of ash (Fraxinus excelsior), caused by Pseudomonas syringae subsp. savastanoi pv. fraxini. I. History, occurrence and symptoms. Eur. J. For. Pathol. 11:306-315.

7b.Janse, J. D. 1981. The bacterial disease of ash (Fraxinus excelsior), caused by Pseudomonas syringae subsp. savastanoi pv. fraxini. II. Etiology and taxonomic considerations. Eur. J. For. Pathol. 11:425-438.

8. Lapage, S. P., P. H. A. Sneath, E. F. Lessel, V. B. D. Skerman, H. P. R. Seeliger, and W. A. Clark (ed.). 1975. International code of nomenclature of bacteria. Bacterio- logical Code (1975 revision). American Society for Microbiology, Washington, D.C.

9. Misaghi, I., and R. G. Grogan. 1969. Nutritional and biochemical comparisons of plant-pathogenic and saprophytic fluorescent pseudomonads. Phytopathology 59:1436-1450.

10. Pyrowolakis, E., and H. C. Welzien. 1974. Studies on the distribution of olive-knot, induced by Pseudomonas savastanoi (Sm.) Stev. in the Greek island of Crete. Phytopathol. Mediterr. 13:118-120.

11. Sands, D. C., M. N. Schroth, and D. C. Hildebrand. 1970. Taxonomy of phytopathogenic pseudomonads. J. Bacteriol. 101:9-23.

12. Skerman, V. B. D., V. McGowan, and P. H. A. Sneath (ed.). 1980. Approved lists of bacterial names. Int. J. Syst. Bacteriol. 30:225-420.

13. Škoric, V. 1938, Jasenov rak i njegov uzročnik (The ash canker disease and its causal organism). Glas. Sumske Pokuse 6:66-97.

14. Smith, C. O. 1928. Oleander bacteriosis in California. Phytopathology 18:503-518.

15. Smith, E. F. 1908. Recent studies on the olive-tubercle organism. Bull. Bur. Plant Ind. U.S. Dep. Agric. 131:2543.

16. Stevens, F. L. 1913. The fungi which cause plant disease. Macmillan, New York.

17. Surico, G., L. Sparapano, P. Lerario, R. D. Durbin, and N. Iacobellis. 1976. Studies on growth-promoting substances by Pseudomonas savastanoi (E. F. Smith) Stevens. Poljopr. Znan. Smotra 39:449-458.

18. Sutic, D., and W. J. Dowson. 1963. The reactions of olive, oleander and ash, cross-inoculated with some strains and forms of Pseudomonas savastanoi (Smith) Stevens. Phytopathol. Z. 46:305-314.

19. Šutic, D., and W. J. Dowson. 1963. Microbial characteristics of some isolates and varieties of Pseudomonas savastanoi (Smith) Stevens. Phytopathol. Z. 49:156-160.

20. Urọ̌sevic, B. 1976. Bakteriální rakovina jasanu, olivy a oleandru. Lesnictvi 22:133-144.

21. Wilson, E. E., M. G. Heskett, M. L. Johnson, and T. Kosuge. 1972. Metabolic behaviour of Pseudomonas savastanoi isolates from olive and oleander on certain carbohydrate and amino substrates. Phytopathology 62:349-355.

22. Wilson, E. E., and A R. Magie. 1963. Physiological, serological and pathological evidence that Pseudomonas tonelliana is identical with Pseudomonas savastanoi. Phytopathology 53:653-659.

23. Young, J. M., D. W. Dye, J. F. Bradbury, C. G. Panagopoulos, and C. F. Robbs. 1978. A proposed nomenclature and classification for plant pathogenic bacteria. N.Z. J. Agric. Res. 21:153-177. 